\title{
ECO-FRIENDLY AGRICULTURAL PRACTICES AND THEIR ASSENT BY FARMERS IN HARYANA STATE OF INDIA
}

\author{
Rohila, A. K. ${ }^{1 *}$ - Kumar, A. ${ }^{1}$ - GHAnghas, B. S. ${ }^{2}$ - MAHALle, S. L. ${ }^{1}$ - Nimbrayan, P. K. ${ }^{3}-$ \\ MAAN, D. S. ${ }^{4}-$ KUMAR, R. ${ }^{5}$ \\ ${ }^{I}$ NAHEP - Indian Council of Agricultural Research, New Delhi-110 012, India \\ ${ }^{2}$ Department of Extension Education, CCSHAU, Hisar-125 004, India \\ ${ }^{3}$ Department of Agricultural Economics, CCSHAU, Hisar-125 004, India \\ ${ }^{4}$ Faculty of Agriculture, Tantia University, Sri Ganganagar-335 001, India \\ ${ }^{5}$ Department of Agriculture and Farmers Welfare, Rewari-123 401, Haryana, India \\ *Corresponding author \\ e-mail: rohillaextension@gmail.com \\ (Received 25 ${ }^{\text {th }}$ Oct 2018; accepted 29 $9^{\text {th }}$ Mar 2019)
}

\begin{abstract}
Intensive agricultural practices coupled with better input services has resulted in exponential growth in crop production in India, particularly in northern region states of the country like Haryana. Though self-sufficiency has been achieved, it was accompanied by negative environmental effects such as serious non-target agricultural pollution. Implementation of eco-friendly smart agricultural practices can effectively overcome such pollution. However, the major constraints in assent and adoption of these practices are not limited only to associate risks and potential benefits, but farmers' attitudes towards knowledge of scientifically validated practices too came into picture. In the presented study, opinions of 180 respondents were explored in personal interviews using a three-point continuum scale for the major constraints (very serious, serious and not so serious) and scores were given as 3,2 and 1, respectively. Weighted mean score (WMS), rank orders, standard deviation, correlation and regression were computed for the better understanding. Results concluded that major constraints for smart agricultural practices in their assent were non-familiarization with improved practices (WMS $=2.46$ ), procedure of registration for weather forecasting (2.37), conservation agriculture is more labour intensive (2.24), lack of training to access e-information (2.39), Climate change effects the seasonal temperature and rainfall (2.76), Slow result of eco- friendly practices (2.54), high initial cost of protected structure (2.52), and lack of proper training for agro-processing and value addition practices (2.42). The results also indicated that 11 independent variables which were included in the study jointly contributed $37.00 \%$ variations in the constraints faced by the farmers in adoption of smart agricultural practices.
\end{abstract}

Keywords: agriculture, adoption, climate, constraints, management and production

\section{Introduction}

The major challenge of Indian agriculture is to produce sufficient food grains as it has long been a priority of the country to achieve food security, as it one of the major challenges posed by shrinking landholdings and the over increasing population. About two-third population of Indian population is directly or indirectly depends on related activities for their livelihoods and this sector occupies almost $43 \%$ of India's total geographical area (Arjun, 2013). About, 85 percent farmer comes under the category of small and marginal landholding. Demands are continuously increasing on agricultural land for food, fibre, and fuel is predicted to increase exponentially in coming decades with continued population growth (Bommarco et al., 2013). Population growth and dietary changes will drive the global food demand to extraordinary levels in the coming 
decades. To keep pace, food production will have to increase $60 \%$ by 2050 (FAO, 2013). Thus, population growth rate of $1.58 \%$, India is predicted to have more than 1.7 billion people by the end of 2050 .

India, with a total of $160 \mathrm{~m}$ ha of cultivated land comprises of only 39 million hectare irrigated by ground water and 22 million hectare by canals whereas about two third of cultivation in India is still depending on monsoon (Dhawan, 2017) and now there is a well-established fact and figures that natural resources such as land, water, forests, livestock, fisheries are deteriorating and degrading at a very fast rate which may be attributed to unmindful agricultural intensification, imbalanced use of fertilizers, overuse and inefficient use of irrigation water and deforestation.

While, other constraints like inadequate marketing channels and infrastructure, long intermediation, lack of accurate and timely market information system etc. are major challenges to the agricultural marketing system in the country. To prevent agricultural non-target pollution, ameliorate its effects and protect the environment in India, while maintaining or increasing crop yields, traditional practices are being re-evaluated and new eco-friendly agricultural practices are being intensively researched and developed (Shen and Du, 2009).

Therefore, there is immense need of adoption of smart agricultural practices (SAPs) to enhance the production and productivity to feed the continuous increasing population through sustainable use of natural resources along with to reduce the input cost, increase the net profit, and generate employment. SAPs, further, takes into consideration the diversity of social, economic and environmental contexts including agro-ecological zones/farming systems where it is to be applied. Implementation herein requires identification of integrated package of climate resilient technologies and practices for management of water, energy, land, crops, livestock, aquaculture etc. at the farm level while considering the linkage between agricultural production and ecosystems services at the landscape level. However, the real picture of overall sustainability and adoption of smart agricultural practices seems to be continued to face many challenges. Keeping in view the above concerns, study was conducted with objective to assess the constraints in adoption of smart agricultural practices.

\section{Materials and methods}

The study was conducted in Haryana state of India during 2017 (Fig. 1). Data were collected from From Hisar and Kaithal because main campus and sub campus of the university is situated in these districts. All respondents were recruited randomly from two districts viz. Hisar from South-West zone and Kaithal from North-East zone and three villages were selected from each district i.e. Ladwa, Shahrwa and Rawalwas Khurd villages from Hisar, whereas, Kaul, Rasina and Bhana villages were selected from Kaithal. Thirty farmers from each selected village were selected randomly. A well-structured and pre-tested questionnaire (see Appendix) was designed and used to survey opinions of a stratified sample of 180 farmers which were engaged in small-scale production. The data was analysed by Statistical Package for the Social Sciences (SPSS). Weighted mean score, rank orders, standard deviation, correlation and regression were computed for the better understanding. The responses of farmers' were obtained on three-point continuum scale in case of constraints (very serious, serious and not so serious) and scores were given as 3,2 and 1, respectively. After that frequency was multiplied with the score $(3,2$ or 1$)$ and total weighted score was obtained and total 
weighted score was divided by total respondents (180) for obtaining weighted mean score (WMS) and according to weighted mean score rank order were given.

$$
\text { Weighted Mean Score (WMS) }=\frac{\mathrm{w} 1 * \mathrm{x} 1+\mathrm{w} 2 * \mathrm{x} 2+\mathrm{w} 3 * \mathrm{x} 3}{n}
$$

where

$\mathrm{W}=$ number of respondents

$\mathrm{x}=$ value of seriousness i.e. Very Serious $\left(\mathrm{x}_{1}\right)-3$, Serious $\left(\mathrm{x}_{2}\right)-2$ and Not so serious $\left(\mathrm{x}_{3}\right)-1$ $\mathrm{n}=$ total number of respondents

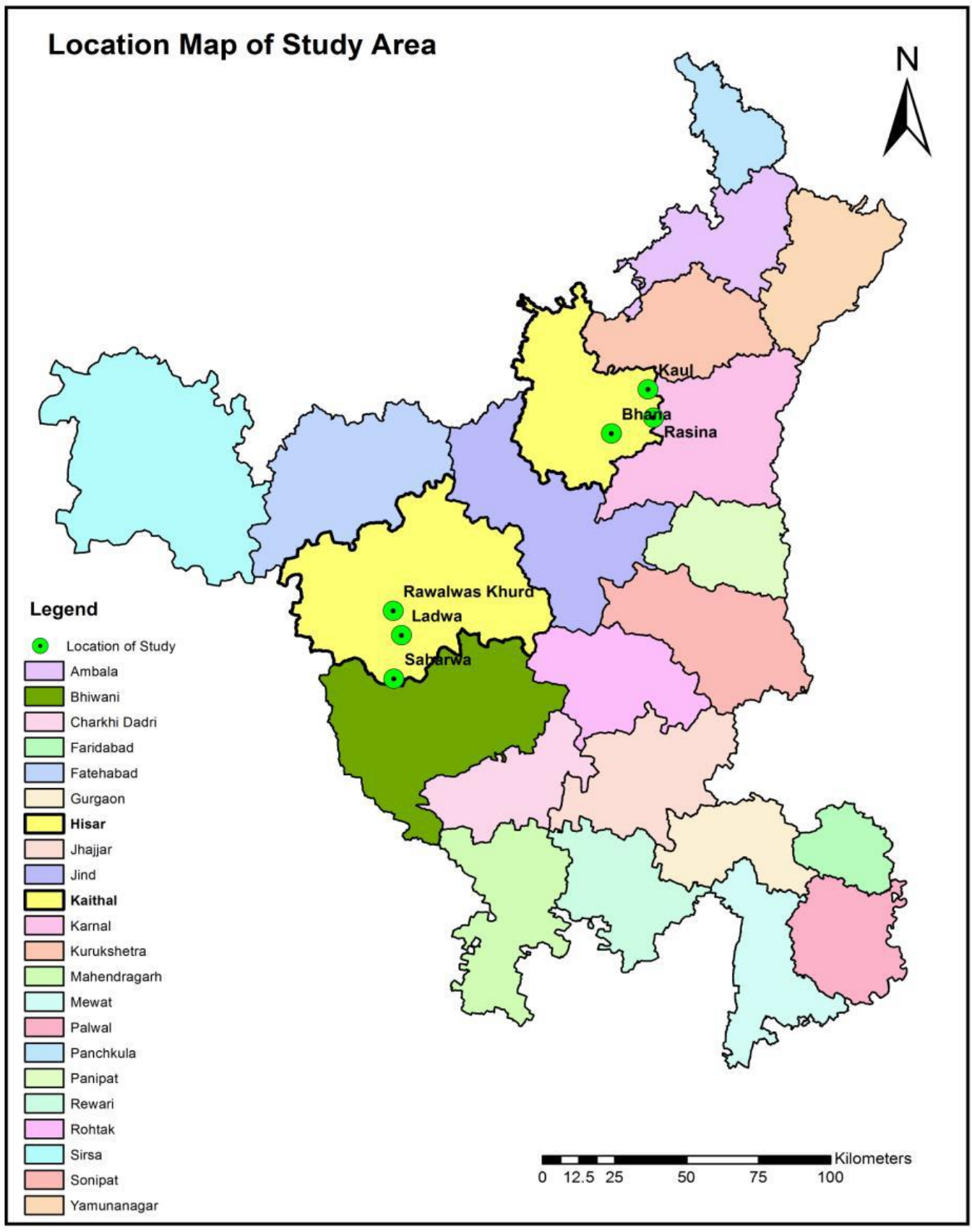

Figure 1. Map of Haryana showing the locale of study 


\section{Results and discussion}

\section{Profile of respondents}

Results pertaining to the personal profile of the farmers indicated in Table 1. It was found that vast majority of the farmers $(78.34 \%)$ belonged to productive age group i.e. young to middle. The age-wise distribution of the respondents is quite natural and expected that working farmers usually come from young and middle aged group. More than $85 \%$ farmers were found to literate from primary to post graduate. Educational status is important and plays a key role in enhancing the knowledge, encouraging and motivating them towards adopting the innovative technologies and their applications. It is generally presumed that higher the educational status higher will be the adoption level. Majority of the farmers had land holding up to 5 acres, followed by 6-10 acre $(36.67 \%)$.

Table 1. Profile of respondents $(n=180)$

\begin{tabular}{|c|c|c|}
\hline Category & Frequency & Percentage \\
\hline \multicolumn{3}{|c|}{ Age } \\
\hline Young (21-39 Years) & 75 & 41.67 \\
\hline Middle (39-57 Years) & 66 & 36.67 \\
\hline Old (57-76 Years) & 39 & 21.66 \\
\hline \multicolumn{3}{|c|}{ Education } \\
\hline Illiterate & 21 & 11.67 \\
\hline Primary & 13 & 7.22 \\
\hline Middle & 19 & 10.56 \\
\hline Metric & 63 & 35.00 \\
\hline Higher secondary & 29 & 16.11 \\
\hline Graduate & 27 & 15.00 \\
\hline Postgraduate & 8 & 4.44 \\
\hline \multicolumn{3}{|c|}{ Land holding } \\
\hline Less than one acre & 15 & 08.33 \\
\hline Up to 5 acres & 83 & 46.11 \\
\hline 6 to 10 acres & 66 & 36.67 \\
\hline 11 to 15 acres & 9 & 5.00 \\
\hline 16 to 20 acres & 1 & 0.56 \\
\hline More than 20 acres & 6 & 3.33 \\
\hline
\end{tabular}

$\mathrm{n}=180$ represents the total number of respondents

\section{Constraints in adoption of sustainable farming}

The examination of the data presented in Table 2 indicated the constraints in adoption of sustainable farming viz., 'not familiar with improved practices' as overall major and serious constraint $(52.78 \%)$ and ranked $1^{\text {st }}$ with highest weighted mean score (WMS) 2.46, followed by 'small and fragmented land holding', 'not aware about training for sustainable farming', 'lack of skill to adopt sustainable farming' and 'lack of finance to adopt improved practices' ranked $2^{\text {nd }}, 3^{\text {rd }}, 4^{\text {th }}$ and $5^{\text {th }}$ with WMS $2.41,2.29$, 2.24 and 2.21, respectively. The major constraint comes in adoption of smart 
agricultural practices is that farmers are not familiar with improved practices and it might be possible due to the fact that clearly farmers develop and use cultural practices they are comfortable with and therefore minimize production risk associated with crop failure or yield reductions. Most farmers perceive these practices to be too costly. While Dsouza et al. (1993) concluded that adoption of sustainable agricultural practices is affected most by the environmental characteristic. Ikerd (1990) states that economic considerations and incentives are needed to encourage change to a different system. Secondly lack of awareness, training and skills about these practices are another factor. So, it is important to organize continuous awareness programs and provide the skill oriented training at local level in farming community. These results are in confirmation with those reported by Kumari (2012).

Table 2. Constraints in adoption of sustainable farming $(n=180)$

\begin{tabular}{c|c|c|c|c|c|c|c}
\hline \multirow{2}{*}{ S. No. } & Sustainable constraints & $\begin{array}{c}\text { Very } \\
\text { serious } \\
(\%)\end{array}$ & $\begin{array}{c}\text { Serious } \\
(\%)\end{array}$ & $\begin{array}{c}\text { Not so } \\
\text { serious } \\
(\%)\end{array}$ & $\begin{array}{c}\text { Total } \\
\text { weighted } \\
\text { score }\end{array}$ & $\begin{array}{c}\text { Weighted } \\
\text { mean score }\end{array}$ & $\begin{array}{c}\text { Rank } \\
\text { order }\end{array}$ \\
\cline { 3 - 6 } 1 & $\begin{array}{c}\text { Small and fragmented land } \\
\text { holding }\end{array}$ & $\begin{array}{c}95 \\
(52.78)\end{array}$ & $\begin{array}{c}63 \\
(35.00)\end{array}$ & $\begin{array}{c}22 \\
(12.22)\end{array}$ & 433 & 2.41 & II \\
\hline 2 & $\begin{array}{c}\text { Lack of skill to adopt } \\
\text { sustainable farming }\end{array}$ & $\begin{array}{c}57 \\
(31.67)\end{array}$ & $\begin{array}{c}110 \\
(61.11)\end{array}$ & $\begin{array}{c}13 \\
(7.22)\end{array}$ & 404 & 2.24 & IV \\
\hline 3 & $\begin{array}{c}\text { Lack of finance to adopt } \\
\text { improved practices }\end{array}$ & $\begin{array}{c}50 \\
(27.78)\end{array}$ & $\begin{array}{c}118 \\
(65.56)\end{array}$ & $\begin{array}{c}12 \\
(6.66)\end{array}$ & 398 & 2.21 & V \\
\hline 5 & $\begin{array}{c}\text { Not aware about training } \\
\text { for sustainable farming }\end{array}$ & $\begin{array}{c}63 \\
(35.00)\end{array}$ & $\begin{array}{c}107 \\
(59.44)\end{array}$ & $\begin{array}{c}10 \\
(5.56)\end{array}$ & 413 & 2.29 & III \\
\hline 5 & $\begin{array}{c}\text { Not familiar with improved } \\
\text { practices }\end{array}$ & $\begin{array}{c}95 \\
(52.78)\end{array}$ & $\begin{array}{c}72 \\
(40.00)\end{array}$ & $\begin{array}{c}13 \\
(7.22)\end{array}$ & 442 & 2.46 & I \\
\hline
\end{tabular}

$\mathrm{n}=180$ represents the total number of respondents

\section{Constraints in adoption of weather forecasting}

A perusal of data presented in Table 3 indicated the weather forecasting viz., 'not aware about the procedure of registration' ranked $1^{\text {st }}$ with highest weighted mean score (WMS) 2.37, followed by 'irregularity in message' ranked $2^{\text {nd }}$ with WMS 2.23. 'Information is useful only for until crop production', 'lack of resources and internet etc.' and 'not proper language of message' ranked $3^{\text {rd }}, 4^{\text {th }}$ and $5^{\text {th }}$ with WMS $2.22,2.19$ and 2.12, respectively. Farmers were not aware about the procedure of registration was ranked top and this may be possibly due to the region that extension personnel do not regularly interact with farmers to discuss climate forecasts. These constraints can be trimmed by providing proper guidance from the experts to the farmers with the help of literature, awareness campaign and mass media about weather forecasting advisory services to the farmers. Oyekale (2015) also reported that infrastructure and human capacities that are needed for attaining such efficiency were acutely lacking. This has also been reported by Murthy (2008) with respect to weather forecasts in Andhra Pradesh. Agricultural extension agents, working with farmers and forecasters could help forecasters to focus on the climate variables and spatial resolutions that matter to farmers and provide feedback from farmers to the forecasters about the performance and utility of the forecasts. They could assist farmers to interpret and apply forecasts for 
making decisions such as the time of planting, choice of crops and crop varieties, application of fertilizers, herbicides, pesticides and irrigation water. These constraints can be overcome by frequent visits by extension personnel along with use of different teaching materials and methods, as extension personnel, rarely interact with farmers as well as the use of different teaching materials like display boards, bulletins (Feleke, 2015) and methods like personal contacts, informal discussion (Rajesh et al., 2016) on changing weather conditions were not given the deserved attention. Weather forecasting advisory services to the farmers and Climate Field Schools are discussed in this context by Stigter (2008).

Table 3. Constraints in adoption of weather forecasting $(n=180)$

\begin{tabular}{c|c|c|c|c|c|c|c}
\hline \multirow{2}{*}{ S. No. } & \multirow{2}{*}{$\begin{array}{c}\text { Weather forecasting } \\
\text { constraints }\end{array}$} & $\begin{array}{c}\text { Very } \\
\text { serious } \\
(\%)\end{array}$ & $\begin{array}{c}\text { Serious } \\
(\%)\end{array}$ & $\begin{array}{c}\text { Not so } \\
\text { serious } \\
(\%)\end{array}$ & $\begin{array}{c}\text { Total } \\
\text { weighted } \\
\text { score }\end{array}$ & $\begin{array}{c}\text { Weighted } \\
\text { mean score }\end{array}$ & $\begin{array}{c}\text { Rank } \\
\text { order }\end{array}$ \\
\hline 1 & $\begin{array}{c}\text { Not aware about the } \\
\text { procedure of registration }\end{array}$ & $\begin{array}{c}95 \\
(52.78)\end{array}$ & $\begin{array}{c}56 \\
(31.11\end{array}$ & $\begin{array}{c}29 \\
(16.11)\end{array}$ & 426 & 2.37 & I \\
\hline 2 & Irregularity in message & $\begin{array}{c}57 \\
(31.67)\end{array}$ & $\begin{array}{c}108 \\
(60.00)\end{array}$ & $\begin{array}{c}15 \\
(8.33)\end{array}$ & 402 & 2.23 & II \\
\hline 3 & $\begin{array}{c}\text { Not proper language of } \\
\text { message }\end{array}$ & $\begin{array}{c}49 \\
(27.22)\end{array}$ & $\begin{array}{c}104 \\
(57.78)\end{array}$ & $\begin{array}{c}27 \\
(15.00)\end{array}$ & 382 & 2.12 & V \\
\hline 5 & $\begin{array}{c}\text { Lack of resources and } \\
\text { internet etc. }\end{array}$ & $\begin{array}{c}50 \\
(27.78)\end{array}$ & $\begin{array}{c}114 \\
(63.33)\end{array}$ & $\begin{array}{c}16 \\
(8.89)\end{array}$ & 394 & 2.19 & IV \\
\hline
\end{tabular}

$\mathrm{n}=180$ represents the total number of respondents

\section{Constraints in adoption of conservation agriculture (CA)}

Data presented in Table 4 indicated the conservation agriculture (CA) constraints viz., 'conservation agriculture is more labour intensive' ranked $1^{\text {st }}$ and major constraints with weighted mean score (WMS) 2.24, followed by 'increasing weed infestation', 'poor soil quality' and 'fragmented land holding' ranked $2^{\text {nd }}, 3^{\text {rd }}$ and $4^{\text {th }}$ with WMS 2.21, 2.18 and 1.43, respectively. The conservation agriculture (CA) constraints viz., conservation agriculture is more labour intensive as well as prominent among farmers because full implementation of the principles of conservation agriculture involves a drastic change in many farm operations. So, there is immense need of proper training programs and policy about CA promotions (Grabowski, 2011; Kudi et al., 2011). A new knowledge base is needed by farmers to establish crops, manage weeds, manage crop residues, respond to newly emerging diseases and insect pests, and manage diverse crops that make the conservation agriculture more labour intensive (Pieri et al., 2002). Moreover, it cannot be reduced to a simple standard technology and thus pioneers and early adopters' face many hurdles before the benefits of conservation agriculture can be revealed (Derpsch, 2008). Also, it is appeared that conservation agriculture is as yet a relatively unknown concept (Kassam et al., 2009). Indeed, conservation agriculture is not an easily transferable single component technology; the appropriateness of conservation agriculture depends on both biophysical and socioeconomic factors and their interactions. 
Table 4. Constraints in adoption of conservation agriculture $(C A)(n=180)$

\begin{tabular}{|c|c|c|c|c|c|c|c|}
\hline \multirow[b]{2}{*}{ S. No. } & \multirow[b]{2}{*}{$\begin{array}{l}\text { Conservation } \\
\text { agriculture constraints }\end{array}$} & \multicolumn{3}{|c|}{ Constraints } & \multirow[b]{2}{*}{$\begin{array}{c}\text { Total } \\
\text { weighted } \\
\text { score }\end{array}$} & \multirow[b]{2}{*}{$\begin{array}{l}\text { Weighted } \\
\text { mean score }\end{array}$} & \multirow[b]{2}{*}{$\begin{array}{l}\text { Rank } \\
\text { order }\end{array}$} \\
\hline & & $\begin{array}{c}\text { Very } \\
\text { serious } \\
(\%) \\
\end{array}$ & $\begin{array}{l}\text { Serious } \\
(\%)\end{array}$ & $\begin{array}{c}\text { Not so } \\
\text { serious } \\
(\%) \\
\end{array}$ & & & \\
\hline 1 & Fragmented land holding & $\begin{array}{c}22 \\
(12.22) \\
\end{array}$ & $\begin{array}{c}34 \\
(18.89) \\
\end{array}$ & $\begin{array}{c}124 \\
(68.89) \\
\end{array}$ & 258 & 1.43 & IV \\
\hline 2 & Poor soil quality & $\begin{array}{c}47 \\
(26.11) \\
\end{array}$ & $\begin{array}{c}119 \\
(66.11) \\
\end{array}$ & $\begin{array}{c}14 \\
(7.78) \\
\end{array}$ & 393 & 2.18 & III \\
\hline 3 & $\begin{array}{c}\text { Increasing weed } \\
\text { infestation }\end{array}$ & $\begin{array}{c}45 \\
(25.00) \\
\end{array}$ & $\begin{array}{c}128 \\
(71.11) \\
\end{array}$ & $\begin{array}{c}7 \\
(3.89) \\
\end{array}$ & 398 & 2.21 & II \\
\hline 4 & $\begin{array}{l}\text { Conservation agriculture } \\
\text { is more labour intensive }\end{array}$ & $\begin{array}{c}53 \\
(29.44)\end{array}$ & $\begin{array}{c}118 \\
(65.56)\end{array}$ & $\begin{array}{c}9 \\
(5.00) \\
\end{array}$ & 404 & 2.24 & $\mathrm{I}$ \\
\hline
\end{tabular}

$\mathrm{n}=180$ represents the total number of respondents

\section{Constraints in adoption of information and communication technologies (ICTs)}

Table 5 described the constraints in adoption of ICTs viz., 'lack of training to access einformation' ranked $1^{\text {st }}$ with highest weighted mean score (WMS) 2.39, followed by 'low internet access and electricity', 'inadequate infrastructural facilities', 'lack of resources and tools', and 'fear that ICTs provides irrelevant content' ranked $2^{\text {nd }}, 3^{\text {rd }}, 4^{\text {th }}$ and $5^{\text {th }}$ with WMS 2.30, 2.25, 2.22 and 2.18, respectively. The first rank was ascribed to the statement that there is lack of training to access e-information and this could be possibly due to the reason that regulatory frameworks for ICTs are not necessarily conducive to widespread scale up of ICT in rural areas. Processes take several years and require many regular visits to monitor and encourage progress, without assurance of success. This can be achieved through information and training campaigns, suitable legislations and policy along with regulatory frameworks, research and development, incentive and credit programs (Friedrich and Kassam, 2009). Therefore, training programs should be organized to overcome the constraints along with to provide infrastructure facilities, resources, tools and internet (Albert, 2014). While Rohila et al. (2017) suggested that low cost ICT tools such as mobile phones etc. should be promoted to provide agricultural information.

Table 5. Constraints in adoption of ICTs $(n=180)$

\begin{tabular}{c|c|c|c|c|c|c|c}
\hline \multirow{2}{*}{ S. No. } & ICTs constraints & $\begin{array}{c}\text { Very } \\
\text { serious } \\
(\%)\end{array}$ & $\begin{array}{c}\text { Serious } \\
(\%)\end{array}$ & $\begin{array}{c}\text { Not so } \\
\text { serious } \\
(\%)\end{array}$ & $\begin{array}{c}\text { Total } \\
\text { weighted } \\
\text { score }\end{array}$ & $\begin{array}{c}\text { Weighted } \\
\text { mean score }\end{array}$ & $\begin{array}{c}\text { Rank } \\
\text { order }\end{array}$ \\
\hline 1 & $\begin{array}{c}\text { Inadequate infrastructural } \\
\text { facilities }\end{array}$ & $\begin{array}{c}55 \\
(30.56)\end{array}$ & $\begin{array}{c}115 \\
(63.89)\end{array}$ & $\begin{array}{c}10 \\
(5.55)\end{array}$ & 405 & 2.25 & III \\
\hline 2 & $\begin{array}{c}\text { Lack of resources and } \\
\text { tools }\end{array}$ & $\begin{array}{c}51 \\
(28.33)\end{array}$ & $\begin{array}{c}118 \\
(65.56)\end{array}$ & $\begin{array}{c}11 \\
(6.11)\end{array}$ & 400 & 2.22 & IV \\
\hline 3 & $\begin{array}{c}\text { Low internet access and } \\
\text { electricity }\end{array}$ & $\begin{array}{c}64 \\
(35.56)\end{array}$ & $\begin{array}{c}106 \\
(58.89)\end{array}$ & $\begin{array}{c}10 \\
(5.55)\end{array}$ & 414 & 2.30 & II \\
\hline 4 & $\begin{array}{c}\text { Fear that ICTs provides } \\
\text { irrelevant content }\end{array}$ & $\begin{array}{c}52 \\
(28.89)\end{array}$ & $\begin{array}{c}108 \\
(60.00)\end{array}$ & $\begin{array}{c}20 \\
(11.11)\end{array}$ & 392 & 2.18 & V \\
\hline 5 & $\begin{array}{c}\text { Lack of training to access } \\
\text { e-information }\end{array}$ & $\begin{array}{c}79 \\
(43.89)\end{array}$ & $\begin{array}{c}92 \\
(51.11)\end{array}$ & $\begin{array}{c}9 \\
(5.00)\end{array}$ & 430 & 2.39 & I \\
\hline
\end{tabular}

$\mathrm{n}=180$ represents the total number of respondents 


\section{Constraints related to climate change}

Table 6 narrated that climate change constraints viz., 'climate change effects the seasonal temperature and rainfall' ranked $1^{\text {st }}$ with highest weighted mean score (WMS) 2.76, followed by 'rapid change in weather conditions' ranked $2^{\text {nd }}$ with WMS 2.49 . Whereas, 'deterioration in the quality of crop produce', 'environmental degradation', 'effect on plant population and yield', and 'probability of droughts and floods' ranked $3^{\text {rd }}, 4^{\text {th }}, 5^{\text {th }}$ and $6^{\text {th }}$ with WMS $2.47,2.35,2.28$ and 2.22 , respectively. The statement climate change effects the seasonal temperature and rainfall was ranked $1^{\text {st }}$ with highest weighted mean score by the respondents and this might be due to the reason that climate change is arguably one of the most important challenge which is faced by farmers, largely due to their geographic exposure, low income, greater reliance on climatesensitive sectors such as agriculture, and weak capacity to adapt to the changing climate. Farmers are adversely affected by climatic variability and change because of their dependency on rain-fed agriculture, with variability in rainfall and temperature directly affecting crop and livestock yields. Empirical results show that climate variability has significant economic costs as a result of periodic floods and droughts, which lead to major macro-economic costs and reductions in economic growth. This increased complexity requires a degree of experience and knowledge, which has to be acquired and learned. For early adopters this learning process and experiential knowledge has therefore involved a lot of trial and error until sufficient local experience and knowledge is accumulated to make the adoption easier (FAO, 2010; Mahato, 2014).

Table 6. Constraints related to climate change $(n=180)$

\begin{tabular}{c|c|c|c|c|c|c|c}
\hline \multirow{2}{*}{ S. No. } & $\begin{array}{c}\text { Climate change } \\
\text { constraints }\end{array}$ & $\begin{array}{c}\text { Very } \\
\text { serious } \\
(\%)\end{array}$ & $\begin{array}{c}\text { Serious } \\
(\%)\end{array}$ & $\begin{array}{c}\text { Not so } \\
\text { serious } \\
(\%)\end{array}$ & $\begin{array}{c}\text { Total } \\
\text { weighted } \\
\text { score }\end{array}$ & $\begin{array}{c}\text { Weighted } \\
\text { mean score }\end{array}$ & $\begin{array}{c}\text { Rank } \\
\text { order }\end{array}$ \\
\cline { 3 - 6 } 1 & $\begin{array}{c}\text { Rapid change in weather } \\
\text { conditions }\end{array}$ & $\begin{array}{c}92 \\
(51.11)\end{array}$ & $\begin{array}{c}85 \\
(47.22)\end{array}$ & $\begin{array}{c}3 \\
(1.67)\end{array}$ & 449 & 2.49 & II \\
\hline 2 & $\begin{array}{c}\text { Environmental degradation } \\
3\end{array}$ & $\begin{array}{c}68 \\
(37.78)\end{array}$ & $\begin{array}{c}107 \\
(59.44)\end{array}$ & $\begin{array}{c}5 \\
(2.78)\end{array}$ & 423 & 2.35 & IV \\
\hline 4 & $\begin{array}{c}\text { Climate change effects the } \\
\text { seasonal temperature and } \\
\text { rainfall }\end{array}$ & $\begin{array}{c}137 \\
(76.11)\end{array}$ & $\begin{array}{c}42 \\
(23.33)\end{array}$ & $\begin{array}{c}1 \\
(0.56)\end{array}$ & 496 & 2.76 & I \\
\hline 5 & $\begin{array}{c}\text { Effect on plant population } \\
\text { and yield }\end{array}$ & $\begin{array}{c}54 \\
(30.00)\end{array}$ & $\begin{array}{c}123 \\
(68.33)\end{array}$ & $\begin{array}{c}7 \\
(1.67)\end{array}$ & 411 & 2.28 & V \\
\hline 6 & $\begin{array}{c}\text { Probability of droughts and } \\
\text { floods }\end{array}$ & $\begin{array}{c}52 \\
(28.89)\end{array}$ & $\begin{array}{c}115 \\
(63.89)\end{array}$ & $\begin{array}{c}13 \\
(7.22)\end{array}$ & 399 & 2.22 & VI \\
\hline
\end{tabular}

$\mathrm{n}=180$ represents the total number of respondents

\section{Constraints in adoption of greenhouse gas mitigation practices}

The data in Table 7 depicted the greenhouse gas mitigation constraints viz., 'slow result of eco-friendly practices' ranked $1^{\text {st }}$ with highest weighted mean score (WMS) 2.54 , followed by 'ignorance about the bed effect of chemical hazardous on health' ranked $2^{\text {nd }}$ with WMS 2.45. While, 'no reward for adoption of environmental measures', 'non- 
availability of package of practices' and 'mostly farmers burn crop residue in the fields' ranked $3^{\text {rd }}, 4^{\text {th }}$ and $5^{\text {th }}$ with WMS 2.38, 2.22 and 1.88 , respectively. The statement slow result of eco-friendly practices ranked $1^{\text {st }}$ may be because of the reason that eco-friendly practices contradicts the knowledge a farmer which he have learned from his experience and been told that the benefits offered by these practices are not obvious in the beginning. However, once the step-wise adoption begins, an eco-friendly practice improves its performance over time (Tebrugge and Bohrnsen, 2000). From the results of the study, it is clear that farmers will more readily adopt sequestration of GHGs if the agricultural extension services, planning and strategies could be improved. These findings are in line with findings of Mukteshawar and Seharawat (2016).

Table 7. Constraints in adoption of greenhouse gas mitigation practices $(n=180)$

\begin{tabular}{c|c|c|c|c|c|c|c}
\hline \multirow{2}{*}{ S. No. } & $\begin{array}{c}\text { Greenhouse gas } \\
\text { mitigation constraints }\end{array}$ & $\begin{array}{c}\text { Very } \\
\text { serious } \\
(\%)\end{array}$ & $\begin{array}{c}\text { Serious } \\
(\%)\end{array}$ & $\begin{array}{c}\text { Not so } \\
\text { serious } \\
(\%)\end{array}$ & $\begin{array}{c}\text { Total } \\
\text { weighted } \\
\text { score }\end{array}$ & $\begin{array}{c}\text { Weighted } \\
\text { mean score }\end{array}$ & $\begin{array}{c}\text { Rank } \\
\text { order }\end{array}$ \\
\cline { 3 - 6 } 1 & $\begin{array}{c}\text { Non-availability of package } \\
\text { of practices }\end{array}$ & $\begin{array}{c}47 \\
(26.11)\end{array}$ & $\begin{array}{c}126 \\
(70.00)\end{array}$ & $\begin{array}{c}7 \\
(3.89\end{array}$ & 400 & 2.22 & IV \\
\hline 2 & $\begin{array}{c}\text { No reward for adoption of } \\
\text { environmental measures }\end{array}$ & $\begin{array}{c}86 \\
(47.78)\end{array}$ & $\begin{array}{c}76 \\
(42.22)\end{array}$ & $\begin{array}{c}18 \\
(10.00)\end{array}$ & 428 & 2.38 & III \\
\hline 5 & $\begin{array}{c}\text { Ignorance about the bed } \\
\text { effect of chemical } \\
\text { hazardous on health }\end{array}$ & $\begin{array}{c}84 \\
(46.67)\end{array}$ & $\begin{array}{c}93 \\
(51.67)\end{array}$ & $\begin{array}{c}3 \\
(1.66)\end{array}$ & 441 & 2.45 & II \\
\hline 5 & $\begin{array}{c}\text { Slow result of eco- friendly } \\
\text { practices }\end{array}$ & $\begin{array}{c}105 \\
(58.33)\end{array}$ & $\begin{array}{c}68 \\
(37.78)\end{array}$ & $\begin{array}{c}7 \\
(3.89)\end{array}$ & 458 & 2.54 & I \\
\hline
\end{tabular}

$\mathrm{n}=180$ represents the total number of respondents

\section{Constraints in adoption of protected cultivation}

The data contained in Table 8 showed the protected cultivation constraints viz., 'high initial cost' ranked $1^{\text {st }}$ as major constraint with highest weighted mean score (WMS) 2.52, followed by 'poor quality of material' ranked $2^{\text {nd }}$ with WMS 2.41. While, 'frequent occurrence of wind storms, hailstorms, rain etc.' and 'problem of nematodes and diseases' ranked $3^{\text {rd }}$ and $4^{\text {th }}$ with WMS 2.23 and 2.04, respectively. The statement high initial cost ranked $1^{\text {st }}$ might be possibly due to the reason that polyhouse cultivation requires quality planting material, inputs, etc. which adds economic burden to the farmers. Singh and Sirohi (2006) also reported that the basic cost of fabrication and the operational cost of the climate-controlled greenhouses are very high, which are not suitable to the growers in India. Therefore, high initial investment, lack of availability of quality planting materials and inputs, poor post-harvest infrastructure and absence of price policy have led to very limited adoption of this technology by few farmers in certain pockets of the country. Above constraints can be countered to enhance farmers' adoption level with the help of manufacturing and financial sector support. It can be increased through capacity building of farmers, research and development coupled with adequate marketing system. Present study got support from the past research study of Ghanghas et al. (2015). 
Table 8. Constraints in adoption of protected cultivation $(n=180)$

\begin{tabular}{c|c|c|c|c|c|c|c}
\hline \multirow{2}{*}{ S. No. } & $\begin{array}{c}\text { Protected cultivation } \\
\text { constraints }\end{array}$ & $\begin{array}{c}\text { Very } \\
\text { serious } \\
(\boldsymbol{\%})\end{array}$ & $\begin{array}{c}\text { Serious } \\
(\%)\end{array}$ & $\begin{array}{c}\text { Not so } \\
\text { serious } \\
(\%)\end{array}$ & $\begin{array}{c}\text { Total } \\
\text { weighted } \\
\text { score }\end{array}$ & $\begin{array}{c}\text { Weighted } \\
\text { mean score }\end{array}$ & $\begin{array}{c}\text { Rank } \\
\text { order }\end{array}$ \\
\hline 1 & High initial cost & $\begin{array}{c}99 \\
(55.00)\end{array}$ & $\begin{array}{c}76 \\
(42.22)\end{array}$ & $\begin{array}{c}5 \\
(2.78)\end{array}$ & 454 & 2.52 & I \\
\hline 2 & Poor quality of material & $\begin{array}{c}78 \\
(43.33)\end{array}$ & $\begin{array}{c}97 \\
(53.89)\end{array}$ & $\begin{array}{c}5 \\
(2.78)\end{array}$ & 433 & 2.41 & II \\
\hline 3 & $\begin{array}{c}\text { Frequent occurrence of } \\
\text { wind storms, hailstorms, } \\
\text { rain etc. }\end{array}$ & $\begin{array}{c}46 \\
(25.56)\end{array}$ & $\begin{array}{c}129 \\
(71.67)\end{array}$ & $\begin{array}{c}5 \\
(2.77)\end{array}$ & 401 & 2.23 & III \\
\hline 4 & $\begin{array}{c}\text { Problem of nematodes and } \\
\text { diseases }\end{array}$ & $\begin{array}{c}25 \\
(13.89)\end{array}$ & $\begin{array}{c}137 \\
(76.11)\end{array}$ & $\begin{array}{c}18 \\
(10.00)\end{array}$ & 367 & 2.04 & IV \\
\hline
\end{tabular}

$\mathrm{n}=180$ represents the total number of respondents

\section{Constraints in adoption agro-processing and value addition practices}

Table 9 elaborated the agro-processing and value addition constraints viz., 'lack of proper training' ranked $1^{\text {st }}$ as major constraint, followed by 'lack of agro-processing unit' ranked $2^{\text {nd }}$ with WMS 2.38. Whereas, 'lack of procurement policy' and 'lack of proper facilities' ranked $3^{\text {rd }}$ and $4^{\text {th }}$ with WMS 2.25 and 2.23 , respectively. However, 'lack of consumption of agro processed food' ranked $5^{\text {th }}$ with lowest WMS 2.13. Lack of proper training among the farmers was encountered as major constraints possibly due to the number of notable factors like socio-economic, contact with extension workers, provision of infrastructure and other institutional factors, which influenced the adoption. Other factors are also reported including society membership, education (Lapar and Pandey, 1999; Weir and Knight, 2000) and household income (Lapar and Simeon, 2004), education levels (Irungu et al., 1998; Lapar and Simeon, 2004) that contribute in adoption of new agricultural technologies. However, these constraints can be adequately addressed through extension agencies by formation of SHGs and by adopting bottom-up approach. While considering these facts, the need-based and skill oriented training awareness campaign including credit support, market-driven and decentralized extension system of the agro-processors to upgrade their knowledge and skills in modern post-harvest technology is strongly recommended. Moreover, provision of credit facilities could change the perceived constraints into enabling factors for adoption of modern postharvest technology enterprises (Meena et al., 2009; Musebe et al., 2013).

\section{Correlation and regression coefficients of farmers' personality traits with constraints encountered in adoption of smart agricultural practices}

Table 10 narrated that correlation coefficient between the farmers' personality traits like education, land holding, cropping system, farming system, mass media exposure, extension contact, risk orientation, economic motivation and innovation proneness had positive and significant correlation. However, remaining traits namely age and irrigation facilities did not show any significant association at 0.05 level of probability. While in case of the partial regression coefficient, the farmers' education and mass media exposure were found significant, whereas, age, land holding, cropping system, farming system, irrigation facilities, extension contact, risk orientation, economic motivation and 
innovation proneness did not show significantly contribution. These finding were found to partially support by the reports of Rajashekar et al. (2017). Further, it is revealed that all the eleven independent variables included in the study jointly contributed $37.00 \%$ variation in the constraints of the respondents regarding in adoption of smart agricultural practices when other factors were kept constant. This means that only $37.00 \%$ of the variation in the dependent variable was due to these variables and remaining $63.00 \%$ variations is due to other variables.

Table 9. Constraints in adoption agro processing and value addition practices $(n=180)$

\begin{tabular}{|c|c|c|c|c|c|c|c|}
\hline \multirow[b]{2}{*}{ S. No. } & \multirow[b]{2}{*}{$\begin{array}{c}\text { Agro processing and } \\
\text { value addition constraints }\end{array}$} & \multicolumn{3}{|c|}{ Constraints } & \multirow[b]{2}{*}{$\begin{array}{c}\text { Total } \\
\text { weighted } \\
\text { score }\end{array}$} & \multirow[b]{2}{*}{$\begin{array}{l}\text { Weighted } \\
\text { mean score }\end{array}$} & \multirow[b]{2}{*}{$\begin{array}{l}\text { Rank } \\
\text { order }\end{array}$} \\
\hline & & $\begin{array}{c}\text { Very } \\
\text { serious } \\
(\%)\end{array}$ & $\begin{array}{l}\text { Serious } \\
(\%)\end{array}$ & $\begin{array}{c}\text { Not so } \\
\text { serious } \\
(\%)\end{array}$ & & & \\
\hline 1 & Lack of proper facilities & $\begin{array}{c}46 \\
(25.56) \\
\end{array}$ & $\begin{array}{c}130 \\
(72.22) \\
\end{array}$ & $\begin{array}{c}4 \\
(2.22) \\
\end{array}$ & 402 & 2.23 & IV \\
\hline 2 & Lack of procurement policy & $\begin{array}{c}53 \\
(29.44) \\
\end{array}$ & $\begin{array}{c}119 \\
(66.11) \\
\end{array}$ & $\begin{array}{c}8 \\
(4.44) \\
\end{array}$ & 405 & 2.25 & III \\
\hline 3 & $\begin{array}{c}\text { Lack of agro-processing } \\
\text { unit }\end{array}$ & $\begin{array}{c}75 \\
(41.67) \\
\end{array}$ & $\begin{array}{c}98 \\
(54.44) \\
\end{array}$ & $\begin{array}{c}7 \\
(3.89) \\
\end{array}$ & 428 & 2.38 & II \\
\hline 4 & Lack of proper training & $\begin{array}{c}82 \\
(45.56) \\
\end{array}$ & $\begin{array}{c}92 \\
(51.11) \\
\end{array}$ & $\begin{array}{c}6 \\
(3.33) \\
\end{array}$ & 436 & 2.42 & I \\
\hline 5 & $\begin{array}{l}\text { Lack of consumption of } \\
\text { agro processed food }\end{array}$ & $\begin{array}{c}38 \\
(21.11)\end{array}$ & $\begin{array}{c}90 \\
(50.00)\end{array}$ & $\begin{array}{c}52 \\
(28.89)\end{array}$ & 384 & 2.13 & $\mathrm{~V}$ \\
\hline
\end{tabular}

Table 10. Correlation and regression coefficients of farmers' personality traits with constraints encountered in adoption of smart agricultural practices

\begin{tabular}{c|c|c|c|c|c}
\hline S. No. & Variables & S.D & $\begin{array}{c}\text { Correlation } \\
\text { coefficient }\end{array}$ & $\begin{array}{c}\text { Regression } \\
\text { coefficient }\end{array}$ & 't' values \\
\hline 1 & Age & 0.772 & $0.082^{\mathrm{NS}}$ & 0.207 & $0.154^{\mathrm{NS}}$ \\
2 & Education & 1.619 & $-0.356^{*}$ & -2.182 & $-3.198^{*}$ \\
3 & Land holding & 0.977 & $-0.366^{*}$ & -1.459 & $-1.291^{\mathrm{NS}}$ \\
4 & Cropping system & 0.787 & $-0.145^{\mathrm{NS}}$ & -2.705 & $-2.2^{\mathrm{NS}}$ \\
5 & Farming system & 0.508 & $-0.349^{*}$ & -3.544 & $-1.409^{\mathrm{NS}}$ \\
6 & Irrigation facilities & 0.524 & $-0.042^{\mathrm{NS}}$ & 1.269 & $0.727^{\mathrm{NS}}$ \\
7 & Mass media exposure & 1.819 & $-0.447^{*}$ & -1.948 & $-3.092^{*}$ \\
8 & Extension contacts & 0.914 & $-0.356^{*}$ & -1.51 & $-1.054^{\mathrm{NS}}$ \\
9 & Risk orientation & 2.782 & $-0.110^{\mathrm{NS}}$ & 0.524 & $1.53^{\mathrm{NS}}$ \\
10 & Economic motivation & 3.998 & $-0.246^{*}$ & -0.478 & $-1.899^{\mathrm{NS}}$ \\
11 & Innovation proneness & 1.028 & $-0.344^{*}$ & -0.723 & $-0.667^{\mathrm{NS}}$ \\
\hline
\end{tabular}

Dependent variable-constraints

*Significant at 0.05 levels

$\mathrm{R}^{2}=0.37$, Constant value $=132.78$

\section{Conclusion}

The results of this study showed that many factors can affect the decisions of farmers to accept and adopt the smart agricultural practices (SAPs), but cost is the most 
important, followed by risks. Therefore, government should emphasize on the problems faced by farmers in adoption of smart agricultural practices (SAPs). Moreover, the action plans which may be more efficient and effective must be formulated and implemented at ground level by the government.

Acknowledgements. Author is highly thankful to CCS Haryana Agricultural University, Hisar (Haryana) India for successful completion of Ph.D. degree.

\section{REFERENCES}

[1] Albert, C. O. (2014): Constraints to effective use of ICT among extension professionals and farmers in extension delivery in rivers state, Nigeria. - Singaporean J. Business Econ. Manag. St. 2(11): 135-142.

[2] Arjun, K. M. (2013): Indian agriculture: status, importance and role in Indian economy. Int. J. of Agri. and Food Sci. Tech. 4(4): 343-346.

[3] Bommarco, R., Kleijn, D., Potts, S. G. (2013): Ecological intensification: harnessing ecosystem services for food security. - Tree 28: 230-238.

[4] Derpsch, R. (2008): Critical Steps in No-Till Adoption. - World Association of Soil and Water Conservation (WASWC), Bangkok, pp. 479-495.

[5] Dhawan, V. (2017): Water and Agriculture in India. - Background Paper for the South Asia Expert Panel during the Global Forum for Food and Agriculture (GFFA).

[6] Dsouza, G., Cyphers, D., Phipps, T. (1993): Factors affecting the adoption of sustainable agricultural practices. - Agricultural and Resource Economics Review 22(2): 159-165.

[7] FAO (2010): Climate-Smart Agriculture: Policies, Practices and Financing for Food Security, Adaptation and Mitigation. - FAO, Rome.

[8] FAO (2013): The State of Food and Agriculture. - FAO, Rome.

[9] Feleke, H. G. (2015): Assessing weather forecasting needs of smallholder farmers for climate change adaptation in the central rift valley of Ethiopia. - J. Earth Sci. Climate Change 6(10): 1-8.

[10] Friedrich, T., Kassam, A. (2009): Adoption of conservation agriculture technologies: constraints and opportunities. - IVth World Congress on Conservation Agriculture, New Delhi, February 2009.

[11] Ghanghas, B. S., Mukteshawar, R., Shehrawat, P. S. (2015): Protected cultivation (polyhouse) in Haryana: Problems and prospects. - Ind. J. of Applied Res. 5(8): 684-685.

[12] Grabowski, P. P. (2011): Constraints to adoption of conservation agriculture in the Angonia highlands of Mozambique: perspectives from smallholder hand-hoe farmers. M.Sc. Thesis, Michigan State University, East Lansing, MI.

[13] Ikerd, J. E. (1990): Agriculture's search for sustainability and profitability. - J. Soil Water Cons. 45: 18-23.

[14] Irungu, P., Mbogo, S., Thorpe, W., Njubi, D. (1998): Factors influencing adoption of Napier grass in smallholder dairying in the highlands of Kenya. - Food, Lands and Livelihoods: Setting Research Agendas for Animal Science, KARI Conference Center, Nairobi, Kenya, 27-30 January.

[15] Kassam A, Friedrich T, Shaxson F, Pretty J. (2009): The spread of conservation agriculture: justification, sustainability and uptake. - Int. J. of Agri. Sust. 7: 292-320.

[16] Kudi, T. M., Bolaji, M., Akinola M. O., Nasa, D. H. (2011): Analysis of adoption of improved maize varieties among farmers in Kwara State, Nigeria. - Int. J. Peace Dev. Stud. 1(3): 8-12.

[17] Kumari, G. (2012): Constraints in adoption of integrated pest management (IPM) practices by rice growing farmers of Jammu division. - Ind. Res. J. Ext. Edu. 2: 15-17. 
[18] Lapar, M. L. A., Pandey, S. (1999): Adoption of soil conservation: the case of the Philippines uplands. - Agri. Econ. 21: 241-256.

[19] Lapar, M. L. A., Simeon, K. E. (2004): Factors affecting adoption of dual-purpose forages in the Philippine uplands. - Agri. Sys. 81(2): 95-114.

[20] Mahato, A. (2014): Climate change and its impact on agriculture. - Int. J. Sci. Res. Publ. 4(4): 1-6.

[21] Meena, M. S., Prasad, M., Singh, R. (2009): Constraints perceived by rural agroprocessors in adopting modern post-harvest technologies. - Ind. Res. J. of Ext. Edu. 9(1): $1-5$.

[22] Mukteshawar, R., Seharawat, P. S. (2016): Constraints analysis in adoption of best farm practices towards sequestration of greenhouse gases. - J. Applied Nat. Sci. 8(1): 88-92.

[23] Murthy, V. R. K. (2008): Seminars on Weather, Climate and Farmers. - INSAM, http://www.agrometeorology.org/files-folder/ (accessed 19 February 2008).

[24] Musebe, R., Adur, S., Phiri, N., Miiro, M., Mogga, M., Asea, G., Otim, M., Kimenye, L. (2013): Upscaling new rice for Africa adoption in northern Uganda and south Sudan: socio-economic and technical prerequisites. $-11^{\text {th }}$ African Crop Science Proceedings, Sowing Innovations for Sustainable Food and Nutrition Security in Africa Entebbe, Uganda, 14-17 October, pp. 577-583.

[25] Oyekale, A. S. (2015): Access to risk mitigating weather forecasts and changes in farming operations in East and West Africa: evidence from a Baseline Survey. Sustainability 7: 14599-14617.

[26] Pieri, C., Evers, G., Landers, J., O'Connell, P., Terry, E. (2002): No-till farming for sustainable rural development. - In: Agriculture and Rural Development. Working Paper, FAO, Rome.

[27] Rajashekar, B., Sudharani, V., Parveen, S. K. N., Shivacharan, G. (2017): Knowledge of farmers about integrated weed management (IWM) practices in major crops. - Int. J. of Farm Sci. 7(1): 33-36.

[28] Rajesh, Godara, A. K., Autade, C. D., Mehta, S. K. (2016): Constraints associated with the use of weather forecasting service. - Asian Sci. 11(2): 125-128.

[29] Rohila, A. K., Yadav, K., Ghanghas, B. S. (2017): Role of information and communication technology (ICT) in agriculture and extension. - J. of App. and Nat. Sci. 9(2): 1097-1100.

[30] Shen, Y. D., Du, Z. Q. (2009): The constraints of environment-friendly agricultural technology development and its countermeasures. - Ecol. Econ. 9: 9-16.

[31] Singh, B., Sirohi, N. P. S. (2006): Protected cultivation of vegetables in India: problems and future prospects. - International Symposium on Greenhouses, Environmental Controls and Inhouse Mechanization for Crop Production in the Tropics and Sub-Tropics. Acta Hort. 710.

[32] Stigter, C. J. (2008): Agrometeorology from science to extension: assessment of needs and provision of services. Invited lecture at the 50th anniversary of the Chinese Academy of Agricultural Sciences, Beijing. - Agriculture, Ecosystems and Environment 126: 153157.

[33] Tebrugge, F., Bohrnsen, A. (2000): Direktsaat - Beurteilung durch Landwirte und Experten in der EU und Nebraska. - Landtechnik 55(1): 17-19.

[34] Weir, H., Knight, J. (2000): Adoption and Diffusion of Agricultural Innovations in Ethiopia: The Role of Education. - CSAE Working Paper Series 2000-05, Centre for the Study of African Economies, University of Oxford. 


\section{APPENDIX}

\section{DEPARTMENT OF EXTENSION EDUCATION CCS HARYANA AGRICULTURAL UNIVERSITY, HISAR-125004}

The Investigator:

Anil Kumar Rohila

Admission No: 2014A21D

Appendix 1

Sr. No.

Mobile N.

1. Name of Respondent:

2. Father's Name:

3. Village:

5. District:

4. Block:

6. Age:

\section{Education}

\begin{tabular}{|c|l|l|}
\hline S. No. & \multicolumn{1}{|c|}{ Qualification } & \\
\hline 1 & Illiterate & \\
\hline 2 & Primary & \\
\hline 3 & Middle & \\
\hline 4 & Metric & \\
\hline 5 & Higher Secondary & \\
\hline 6 & Graduate & \\
\hline
\end{tabular}

\section{Land Holding}

\begin{tabular}{|c|l|l|}
\hline S. No. & Particular & \\
\hline 1 & Landless & \\
\hline 2 & Less than one acre & \\
\hline 3 & Up to 5 acres & \\
\hline 4 & 6 to 10 acres & \\
\hline 5 & 11 to 15 acres & \\
\hline 6 & 16 to 20 acres & \\
\hline 7 & More than 20 acres & \\
\hline
\end{tabular}

\section{Cropping System}

\begin{tabular}{|c|l|c|c|}
\hline S. No. & \multicolumn{1}{|c|}{ Particulars } & Yes & No \\
\hline 1 & Rice-Wheat & & \\
\hline 2 & Cotton-Wheat & & \\
\hline 3 & Sugarcane Based & & \\
\hline 4 & Rice-Other crops & & \\
\hline 5 & Other crops-Wheat & & \\
\hline 6 & Cotton-Other crops & \\
\hline
\end{tabular}




\begin{tabular}{|c|l|l|l|}
\hline 7 & Bajra/Jwar/Gwar-Wheat & & \\
\hline 8 & Bajra/Jwar/Gwar-Fallow & & \\
\hline 9 & Fallow-Wheat & & \\
\hline 10 & Bajra/Fallow-Mustard & & \\
\hline 11 & Bajra/Fallow-Pulses & & \\
\hline 12 & Other Rotation & & \\
\hline
\end{tabular}

\section{Farming System}

10. Farming System Particulars
\begin{tabular}{|c|l|c|c|}
\hline S. No. & \multicolumn{1}{|c|}{ Yes } & No \\
\hline 1 & Livestock & & \\
\hline 2 & Poultry & & \\
\hline 3 & Fisheries & & \\
\hline 4 & Forestry & & \\
\hline 5 & Agro-forestry & & \\
\hline 6 & Mushroom cultivation & & \\
\hline 7 & Bee keeping & & \\
\hline 8 & Organic farming & & \\
\hline 9 & Floriculture & & \\
\hline 10 & Poly house nursery & & \\
\hline 11 & Poly house vegetable production & & \\
\hline
\end{tabular}

\section{Irrigation Facilities}

\begin{tabular}{|c|l|c|c|}
\hline S. No & \multicolumn{1}{|c|}{ Particulars } & Yes & No \\
\hline 1 & Submersible Pump & & \\
\hline 2 & Tube well & & \\
\hline 3 & Canal & & \\
\hline 4 & Others & & \\
\hline
\end{tabular}

\section{Farm Power}

\begin{tabular}{|c|l|l|}
\hline S. No & \multicolumn{1}{|c|}{ Particulars } & \\
\hline 1 & No draft animal & \\
\hline 2 & $1-2$ draft animal & \\
\hline 3 & $3-4$ draft animal & \\
\hline 4 & one or more prestige animal & \\
\hline 5 & Tractor & \\
\hline
\end{tabular}

\section{Mass Media Exposure}

\begin{tabular}{|c|l|l|}
\hline S. No & Particulars & \\
\hline 1 & Do you listen radio? & Yes/No \\
\hline 2 & If yes. How frequently? & Daily/often/sometimes \\
\hline 3 & Do you watch agriculture related T.V. programms? & Yes/No \\
\hline 4 & If yes. How frequently? & Daily/often/sometimes \\
\hline
\end{tabular}




\begin{tabular}{|l|l|l|}
\hline 5 & Do you read newspaper? & Yes/No \\
\hline 6 & If yes. How often? & Daily/often/sometimes \\
\hline 7 & Do you read farm magazines? & Yes/No \\
\hline 8 & Do you call Kisan Sewa Kendra for queries? & Yes/No \\
\hline 9 & Do you search online solution for your problems? & Yes/No \\
\hline
\end{tabular}

14. Extension Contact

\begin{tabular}{|c|l|l|l|l|l|l|}
\hline \multirow{2}{*}{ S. No. } & Extension Official & \multicolumn{5}{|c|}{ Frequency of Contact } \\
\cline { 5 - 7 } & & Weekly & Fortnightly & Monthly & $\begin{array}{c}\text { Whenever } \\
\text { needed }\end{array}$ & None \\
\hline 1 & ADOs & & & & & \\
\hline 2 & SDAO/SMS & & & & & \\
\hline 3 & Scientists & & & & & \\
\hline 4 & Progressive farmer & & & & & \\
\hline 5 & NGO & & & & & \\
\hline 6 & Others & & & & & \\
\hline & Total & & & & & \\
\hline
\end{tabular}

\section{Economic Motivation}

\begin{tabular}{|c|c|c|c|c|c|c|}
\hline $\begin{array}{l}\text { S. } \\
\text { No. }\end{array}$ & Statements & SA & $\mathbf{A}$ & $\mathbf{N}$ & $\mathbf{D}$ & SD \\
\hline 1 & A farmer should work toward larger yields and economic profit & & & & & \\
\hline 2 & The most successful farmer is one, who makes the most profit & & & & & \\
\hline 3 & $\begin{array}{l}\text { A farmer should try any new farming idea which may earn him more } \\
\text { money }\end{array}$ & & & & & \\
\hline 4 & $\begin{array}{l}\text { A farmer should grow cash crops to increase monetary profits in } \\
\text { comparison to growing of food crops for home consumption }\end{array}$ & & & & & \\
\hline 5 & $\begin{array}{l}\text { It is difficult for the farmers' children to make good start, unless he } \\
\text { provides them with economic assistance }\end{array}$ & & & & & \\
\hline 6 & $\begin{array}{l}\text { A farmer must earn his living but the most important thing in life } \\
\text { cannot be defined in economic terms }\end{array}$ & & & & & \\
\hline
\end{tabular}

16. Innovation proneness

\begin{tabular}{|c|l|l|l|}
\hline S. No & \multicolumn{1}{|c|}{ Statements } & Most Like & Least like \\
\hline (A) 1 & $\begin{array}{l}\text { I try to keep myself up to date with information of any improved farm } \\
\text { practice, but that does not mean that I try out all the new methods on my } \\
\text { farm. }\end{array}$ & & \\
\hline 2 & I fell restless, till I try out the improved farm practice, I heard about. & & \\
\hline 3 & $\begin{array}{l}\text { They talk of many improved farm practices these days but who knows if } \\
\text { they are better than the old one. }\end{array}$ & & \\
\hline (B) 1 & I am cautious about trying a new practice. & $\begin{array}{l}\text { After all our forefathers were wise about their farm practices and I don't } \\
\text { see any reason for changing the old methods }\end{array}$ & \\
\hline 2 & $\begin{array}{l}\text { Often improved farm practices are not successful. However, they are } \\
\text { promising I would surely like to accept them. }\end{array}$ & & \\
\hline
\end{tabular}




\begin{tabular}{|c|l|l|l|}
\hline (C)1 & $\begin{array}{l}\text { From time to time, I have heard from several improved farm practices } \\
\text { and I have tried out most them in last few years, }\end{array}$ & $\begin{array}{l}\text { I usually wait to see what results my neighbours obtain before I try out } \\
\text { the improved farm practices. }\end{array}$ & \\
\hline 3 & Somehow, I believe that the traditional ways of farming are the best. & & \\
\hline
\end{tabular}

\section{Appendix 2}

Constraints in adoption of sustainable farming

\begin{tabular}{|c|l|c|c|c|}
\hline \multicolumn{1}{|c|}{$\begin{array}{c}\text { S. } \\
\text { No. }\end{array}$} & \multicolumn{1}{|c|}{ Sustainable constraints } & \multicolumn{2}{c|}{ Constraints } \\
\cline { 5 - 5 } & & $\begin{array}{c}\text { Very } \\
\text { serious }\end{array}$ & Serious & $\begin{array}{c}\text { Not so } \\
\text { serious }\end{array}$ \\
\hline 1 & Small and fragmented land holding & & & \\
\hline 2 & Lack of skill to adopt sustainable farming & & & \\
\hline 3 & Lack of finance to adopt improved practices & & & \\
\hline 4 & Not aware about training for sustainable farming & & & \\
\hline 5 & Not familiar with improved practices & & & \\
\hline
\end{tabular}

\section{Constraints in adoption of weather forecasting}

\begin{tabular}{|c|l|c|c|c|}
\hline \multirow{2}{*}{$\begin{array}{c}\text { S. } \\
\text { No. }\end{array}$} & Weather forecasting constraints & \multicolumn{2}{|c|}{ Constraints } \\
\cline { 4 - 5 } & & $\begin{array}{c}\text { Very } \\
\text { serious }\end{array}$ & Serious & $\begin{array}{c}\text { Not so } \\
\text { serious }\end{array}$ \\
\hline 1 & Not aware about the procedure of registration & & & \\
\hline 2 & Irregularity in message & & & \\
\hline 3 & Not proper language of message & & & \\
\hline 4 & Lack of resources and internet etc. & & & \\
\hline 5 & Information is useful only for until crop production & & & \\
\hline
\end{tabular}

\section{Constraints in adoption of conservation agriculture (CA)}

\begin{tabular}{|c|l|l|l|l|}
\hline \multirow{2}{*}{$\begin{array}{c}\text { S. } \\
\text { No. }\end{array}$} & \multicolumn{1}{|c|}{ Conservation agriculture constraints } & \multicolumn{2}{c|}{ Constraints } \\
\cline { 5 - 5 } & & $\begin{array}{c}\text { Very } \\
\text { serious }\end{array}$ & Serious & $\begin{array}{c}\text { Not so } \\
\text { serious }\end{array}$ \\
\hline 1 & Fragmented land holding & & & \\
\hline 2 & Poor soil quality & & & \\
\hline 3 & Increasing weed infestation & & & \\
\hline 4 & Conservation agriculture is more labour intensive & & & \\
\hline
\end{tabular}

Constraints in adoption of ICTs

\begin{tabular}{|c|l|c|c|c|}
\hline \multicolumn{1}{c|}{$\begin{array}{c}\text { S. } \\
\text { No. }\end{array}$} & \multicolumn{1}{|c|}{ ICTs constraints } & \multicolumn{2}{c|}{ Constraints } \\
\cline { 4 - 5 } & & $\begin{array}{c}\text { Very } \\
\text { serious }\end{array}$ & Serious & $\begin{array}{c}\text { Not so } \\
\text { serious }\end{array}$ \\
\hline 1 & Inadequate infrastructural facilities & & & \\
\hline 2 & Lack of resources and tools & & & \\
\hline 3 & Low internet access and electricity & & & \\
\hline
\end{tabular}




\begin{tabular}{|c|l|l|l|l|}
\hline 4 & Fear that ICTs provides irrelevant content & & & \\
\hline 5 & Lack of training to access e-information & & & \\
\hline
\end{tabular}

\section{Constraints related to climate change}

Constraints related to climate change
\begin{tabular}{|c|l|c|c|c|}
\hline \multicolumn{1}{|c|}{$\begin{array}{c}\text { S. } \\
\text { No. }\end{array}$} & \multicolumn{1}{|c|}{ Climate change constraints } & $\begin{array}{c}\text { Very } \\
\text { serious }\end{array}$ & Serious & $\begin{array}{c}\text { Not so } \\
\text { serious }\end{array}$ \\
\hline 1 & Rapid change in weather conditions & & & \\
\hline 2 & Environmental degradation & & & \\
\hline 3 & $\begin{array}{l}\text { Climate change effects the seasonal temperature and } \\
\text { rainfall }\end{array}$ & & & \\
\hline 4 & Deterioration in the quality of crop produce & & & \\
\hline 5 & Effect on plant population and yield & & & \\
\hline 6 & Probability of droughts and floods & & & \\
\hline
\end{tabular}

Constraints in adoption of greenhouse gas mitigation practices

\begin{tabular}{|c|c|c|c|c|}
\hline \multirow{2}{*}{$\begin{array}{l}\text { S. } \\
\text { No. }\end{array}$} & \multirow[b]{2}{*}{ Greenhouse gas mitigation constraints } & \multicolumn{3}{|c|}{ Constraints } \\
\hline & & $\begin{array}{l}\text { Very } \\
\text { serious }\end{array}$ & Serious & $\begin{array}{l}\text { Not so } \\
\text { serious }\end{array}$ \\
\hline 1 & Non-availability of package of practices & & & \\
\hline 2 & No reward for adoption of environmental measures & & & \\
\hline 3 & $\begin{array}{l}\text { Ignorance about the bed effect of chemical hazardous on } \\
\text { health }\end{array}$ & & & \\
\hline 4 & Slow result of eco- friendly practices & & & \\
\hline 5 & Mostly farmers burn crop residue in the fields & & & \\
\hline
\end{tabular}

\section{Constraints in adoption of protected cultivation}

\begin{tabular}{|c|l|c|c|c|}
\hline & & $\begin{array}{c}\text { Very } \\
\text { serious }\end{array}$ & Serious & $\begin{array}{c}\text { Not so } \\
\text { serious }\end{array}$ \\
\hline 1 & High initial cost & & & \\
\hline 2 & Poor quality of material & & & \\
\hline 3 & Frequent occurrence of wind storms, hailstorms, rain etc. & & & \\
\hline 4 & Problem of nematodes and diseases & & & \\
\hline
\end{tabular}

Constraints in adoption agro processing and value addition practices

\begin{tabular}{|c|l|c|c|c|}
\hline \multicolumn{1}{c}{$\begin{array}{c}\text { S. } \\
\text { No. }\end{array}$} & \multicolumn{1}{c}{$\begin{array}{c}\text { Agro processing and value } \\
\text { addition constraints }\end{array}$} & $\begin{array}{c}\text { Cery } \\
\text { serious }\end{array}$ & Serious & $\begin{array}{c}\text { Not so } \\
\text { serious }\end{array}$ \\
\cline { 5 - 5 } & & & & \\
\hline 1 & Lack of proper facilities & & & \\
\hline 2 & Lack of procurement policy & & & \\
\hline 3 & Lack of agro-processing unit & & & \\
\hline 4 & Lack of proper training & & & \\
\hline 5 & Lack of consumption of agro processed food & & \\
\hline
\end{tabular}

